\title{
Investigation of Some Morphological Traits of Boer $x$ Hair F1 Crossbred and Pure Hair Goat Kids Raised in Semi- Intensive Conditions
}

\author{
Investigación de Algunos Rasgos Morfológicos en Caprinos de Pelaje \\ Natural Raza Boer $x$ Cruzados y Criados en Condiciones Semi-Intensivas
}

Memis Bolacali ${ }^{1}$; Yahya Öztürk²; Orhan Yilmaz³ ${ }^{3}$ Mürsel Küçük ${ }^{3}$ \& Mehmet Akif Karslı

BOLACALI, M.; ÖZTÜRK,Y.; YILMAZ, O.; KÜÇÜK, M. \& KARSLI, M. A. Investigation of some morphological traits of Boer x Hair F1 crossbred and pure hair goat kids raised in semi-intensive conditions. Int. J. Morphol., 35(4):1502-1511, 2017.

SUMMARY: The aim of the study was to determine various morphological characteristics from birth to the age of 150 th day of Boer x Hair goat F1 crossbred (BH) kids and pure Hair goat (HG) kids raised in semi-intensive conditions and reveal factors such as the effects of genotype, dam age, dam's live weight, year, birth type and sex on this parameter. This study was applied between the years 2011-2012 in Çatak in the Van region and between the years 2013-2014 at the Yuzuncu Yil University Research and Practice Farm. Various body measurements; wither height, back height, rump height, sacrum height, body length, chest length, chest depth, chest circumference, circumference of leg, cannon bone circumference, chest width, front-rump width, mid-rump width were determined 29.8, 28.4, 28.7, 26.2, 28.7, 17.0, 13.3, 30.4, 26.9, 5.2, 5.9, 6.0, and 8.7 $\mathrm{cm}$ at birth, respectively; 43.8, 43.8, 44.6, 40.6, 43.6, 22.2, 19.3, 51.7, $41.4,6.6,9.2,9.3$, and $11.3 \mathrm{~cm}$ at 60th day, respectively; 56.1, 53.4, 54.4, 47.5, 53.3, 27.3, 24.1, 61.4, 49.6, 7.3, 10.6, 11.1, and 13.2 cm at 150th day, respectively for BH kids; 27.3, 25.9, 29.3, 25.3, 27.1, 15.9, 12.3, 29.0, 21.3, 5.1, 5.0, 5.6, and 7.4 cm at birth, respectively; $40.4,40.1,42.9,37.6,40.5,22.3,18.4,48.1,36.4,6.0,7.9,9.1$, and $10.8 \mathrm{~cm}$ at 60 th day, respectively; 50.3, 49.2, 51.0, 45.7, 50.4, 27.5, 22.9, 57.3, 43.4, 6.5, 9.5, 10.7, and $11.9 \mathrm{~cm}$ at 150th day, respectively for HG kids. When all of the data was considered, it was concluded that the BH kids are much better than the HG kids for both morphological and zoometric values.

KEY WORDS: Boer x Hair goat F1 crossbred; Hair goat; Kids; Morphological traits.

\section{INTRODUCTION}

In recent years priority in demand to goat meat has shifted towards a meat quality. Therefore, high quality goat meat production has become an essential strategy for the meat industry to supply the demand. Goat meat producing developed countries are now looking at ways in which how genetically modified goats or different genotypes can improve the quality of meat production.

In general it is important to focus on the genotypes that have high reproductive rate, growth rate and excellent carcass characteristics (dressing percentage, muscle distribution and lean:fat:bone ratio). Although in this respect species like cattle, pig and sheep have been studied more frequently and new genotypes (breeding) from these species have been developed, goat breeding for meat production have yet to be developed fully. Boer goats yield high carcass and hence used in the world for kids production as a means of increasing meat production.

According to 2014 statistics, there are 10.42 million goats in Turkey. This number puts Turkey 19th in goat production in the world (FAO, 2016; TUIK, 2016), which indicates importance of goat production. Widespread goat production is present in Turkey since its natural, economic, cultural and farming conditions are very much suitable for goat production. Among livestock farming sector, meat and milk production from goat is increasing each year. There are three types of goat production in Turkey: Hair goat,

\footnotetext{
${ }^{1}$ Siirt University, Faculty of Veterinary Medicine, Department of Animal Breeding and Husbandry, Siirt, Turkey.

${ }^{2}$ Mehmet Akif Ersoy University, Burdur vocational school, Program of Meat and Meat Products, Burdur, Turkey.

${ }^{3}$ Yuzuncu Yil University, Faculty of Veterinary Medicine, Department of Animal Breeding and Husbandry, Van, Turkey.

${ }^{4}$ Kirikkale University, Department of Animal Nutrition, Faculty of Veterinary Medicine, Kırıkkale, Turkey.

This research was supported financially by the Office of Scientific Research Projects of Yuzuncu Yil University under Grant [number 2011-VF-B035].
} 
Angora goat and Milk goat. Hair goats constitute most of the goat population in Turkey. This is followed by pure or crossbred milk goats such as Saanen and Malta goats. In Turkey a region-wise number of goat population decreases as follows: the Mediterranean Region, the Southeastern Anatolia Region, the Eastern Anatolia Region, the Aegean Region, the Marmara Region, the Central Anatolia Region and the Black Sea Region (TUIK, 2016).

Production of goat meat and its products in Turkey is mainly based on a HG. According to the data of 2015, HG constitutes 98.02 of the presence of total goats (TUIK). Goat breeders under extensive conditions in Turkey have reared lowproductive $\mathrm{HG}$, as this breed have well adapted to the harsh environment (Daskiran et al., 2010).

The Boer goat was bred during the start of the 20th century by a Dutch scientist in the South African Republic using the selection process. Boer goats were exported to countries as a means of increasing meat production. The Boer goat was exported to Australia in the 1990's and in 1993 to New Zealand. In the same year, it was exported from New Zealand to the United States of America where the American Boer Goat Association was formed. This association worked to improve the meat industry of the Boer goat and to form tangible standards for the Boer breed. As well as breeding a pure breed, a breed was crossbred for the general use of commercial meat production. In this context, Boer x Spanish, Boer x Ankara goat and Boer x Nubian were frequently crossbreed (Malan, 2000; Urge et al., 2004).

Today Boer goat is the best breed in the world for its outstanding carcass quality and its high growth rates (Devendra $\&$ Burns, 1984). The most important features of Boer goats are that it has a high genetic potential, an exceptional resistance to diseases, an excellent adaptation both to hot and dry climate and harsh environments (Malan). They also show distinguished morphological features of such, it has a white body with distinctive brown or brick red head and long, pendulous ears. In Turkey, although there are a number of crossbred and breeding programs developed towards Milk goats, programs (or studies) are limited or lacking for Meat goats.

To increase meat yield from domestic breeds requires genetic improvement of its live weight and body measurements. Body measurements are vital measurements for defining animals numerically, comparison of animals within the same breed following growth and development of animals, determining early selection criteria for certain production trait and the evaluation of animals for breeding. These measurements provide very important clues for traits affected by the environment and the nutrition during the development of breed. The physical measurements are important in studies of genetic diversity for considering the variation existing among various breed groups and also allowing for breed identification (Epstein, 1953; Mason, 1988). Furthermore, body measurements are also useful for evaluating the results of genetic progress and selection. Moreover, some body measurements like chest girth are a useful tool in predicting weight of the goat. Additionally, some body measurements could create the fundamental for the assignment of performance recording to the farmers and allows a more impressive planning of the selection process and also allows an adequate economical qualification of the studied breeds. (Olatunji-Akioye \& Adeyemo, 2009). Some environmental factors such as genotype, sex, birth type, nutrition, age and year of birth, mother's age have some impact on the body measurements (Mohammed \& Amin, 1997; Riva et al., 2004; Ugur et al., 2004).

Some body measurements are used as criteria for classification of goats. At the same time, various body measurements help to determine quantitative characteristics and to develop proper selection criteria. Body measurements and other qualitative characters are also defining characters for a breed as well as economically important characters (Mohammed \& Amin).

The most commonly used body measurements in small ruminants are; head length, head depth, width between shoulders, body length, wither height, sacrum height, chest length, chest circumference, cannon bone circumference and so an (Akçapınar \& Özbeyaz, 1999; Yılmaz et al., 2013). There is a positive correlation between milk and meat production of species or breed and body measurement (height, depth, length and width). The length and width of these values should be enough for animals used as stockers (Özcan, 1977).

For genetic improvement and to increase production in Hair goats, use of Boer goat, particularly in Turkey, and agroecological zones, is limited. The aim of this study was to determine various morphological characteristics from birth to the 150th day of Boer x Hair goat F1 crossbred and pure Hair goat kids raised in semi-intensive conditions and reveal factors such as the effects of genotype, dam age, dam's live weight, year, birth type and sex on this parameter.

\section{MATERIAL AND METHOD}

This experiment was carried out with a total of 125 kids, 49 in 2012 and 76 in 2014. The experiment was conducted at Çatak county of Van province with a Project supported financially by Yüzüncü Y1l University Office of Scientific Research Projects Grant (number 2011-VF-B035). 
Kids were weighted and tagged with plastic tags within one day of birth. Tag number, birth weight, some body measurements, birth date, birth type, sex, tag number of mother, mother's live weight at birth and mother's age were recorded after birth of each kid. Kids were kept with their dame for three days after birth. Thus, they were kept with their dames at night and separated at morning. Kids were weaned at the age of 60th days. Kids were fed 100 $\mathrm{gr} / \mathrm{d} /$ head of kids starter feed and ground alfalfa hay ad libitum level and also had free access to clean water during their suckling period. Kids grazed on pasture after weaning.

Body measurements were determined every 30 days from birth to the age of 150 days and thus, $30,60,90,120$, and 150th days body measurements were estimated via interpolation method. But in this study, only at birth, 60th (at weaning), and 150th days values of body measurements are given.

Following model was used for different body measurements during growth period. The model: Yijklm= $\mathrm{m}+\mathrm{Gi}+\mathrm{Aj}+\mathrm{Wk}+\mathrm{Tl}+\mathrm{Sm}+\mathrm{eijklmn}$ and where: $\mathrm{m}$ : mean of population for examined trait, Gi: the effect of genetype (i: $\mathrm{BH}$ and $\mathrm{HG}$ ), $\mathrm{Aj}$ : the effect of dame age ( $\mathrm{j}: 2 \ldots \geq 6$ year old), Wk: the effect of dame live weight (k: $30.00-35.00$ $\mathrm{kg}, 35.01-40.00 \mathrm{~kg}, 40.01-45.00 \mathrm{~kg}, 45.01-50.00 \mathrm{~kg}$ and $\geq 50.01$ dame live weight), Tl: the effect of birth type (1: single, twin and triplets), Sm: the effect of sex (m: male and female), eijklmn: error term. It was assumed that there was no significant interaction among evaluated factors and the sum impact of factors on their sub-group was zero.

Different body measurements of kids at different periods were analyzed using the general linear model (GLM) procedure of the SAS (SAS, 2002). Duncan's multiple range tests was used for multiple comparisons in important subgroups.

\section{RESULTS}

The results are summarized in Tables I-VII. Specifically, the wither and the back heights at the Table I,

Table I. Least square means, significance and multiple comparison test results for wither and back height of goats at different periods (cm).

\begin{tabular}{|c|c|c|c|c|c|c|c|c|c|c|c|c|}
\hline \multirow{3}{*}{ Factors } & \multicolumn{6}{|c|}{ Wither Height } & \multicolumn{6}{|c|}{ Back Height } \\
\hline & \multicolumn{2}{|r|}{ Birth } & \multicolumn{2}{|c|}{$\begin{array}{c}60^{\text {th }} \text { day } \\
\text { (weaning) }\end{array}$} & \multicolumn{2}{|c|}{$150^{\text {th }}$ day } & \multicolumn{2}{|r|}{ Birth } & \multicolumn{2}{|c|}{$\begin{array}{l}60^{\text {th }} \text { day } \\
\text { (weaning) }\end{array}$} & \multicolumn{2}{|c|}{$150^{\text {th }}$ day } \\
\hline & $\mathrm{n}$ & Mean \pm SD & $\mathrm{n}$ & Mean \pm SD & $\mathrm{n}$ & Mean \pm SD & $\mathrm{n}$ & Mean \pm SD & $\mathrm{n}$ & Mean \pm SD & $\mathrm{n}$ & Mean \pm SD \\
\hline General & 125 & $29.2 \pm 0.37$ & 107 & $43.3 \pm 0.57$ & 104 & $54.1 \pm 0.53$ & 125 & $28.0 \pm 0.32$ & 107 & $43.4 \pm 0.49$ & 104 & $52.4 \pm 0.48$ \\
\hline Genotype & & $*$ & & $*$ & & $* * *$ & & $*$ & & $* *$ & & $* *$ \\
\hline $\mathrm{BH}$ & 80 & $29.8 \pm 0.59$ & 68 & $43.8 \pm 0.84$ & 66 & $56.1 \pm 0.84$ & 80 & $28.4 \pm 0.55$ & 68 & $43.8 \pm 0.71$ & 66 & $53.4 \pm 0.76$ \\
\hline $\mathrm{HG}$ & 45 & $27.3 \pm 0.80$ & 39 & $40.4 \pm 1.14$ & 38 & $50.3 \pm 1.13$ & 45 & $25.9 \pm 0.74$ & 39 & $40.1 \pm 0.95$ & 38 & $49.2 \pm 1.02$ \\
\hline Dame Age & & $*$ & & NS & & NS & & NS & & $*$ & & NS \\
\hline 2 & 19 & $28.4 \pm 0.89^{c}$ & 15 & $42.6 \pm 1.32$ & 15 & $54.5 \pm 1.30$ & 19 & $27.7 \pm 0.83$ & 15 & $43.9 \pm 1.10^{\mathrm{bc}}$ & 15 & $52.7 \pm 1.18$ \\
\hline 3 & 18 & $30.3 \pm 1.20^{\mathrm{ab}}$ & 13 & $43.9 \pm 1.66$ & 12 & $54.9 \pm 1.64$ & 18 & $28.5 \pm 1.13$ & 13 & $42.6 \pm 1.38^{\mathrm{abc}}$ & 12 & $50.7 \pm 1.48$ \\
\hline 4 & 22 & $30.0 \pm 1.06^{\mathrm{a}}$ & 20 & $43.2 \pm 1.59$ & 20 & $53.3 \pm 1.57$ & 22 & $26.9 \pm 0.99$ & 20 & $41.2 \pm 1.32^{\mathrm{ab}}$ & 20 & $51.4 \pm 1.42$ \\
\hline 5 & 35 & $27.6 \pm 0.73^{b c}$ & 31 & $40.0 \pm 1.08$ & 30 & $50.8 \pm 1.07$ & 35 & $26.5 \pm 0.69$ & 31 & $39.6 \pm 0.90^{\mathrm{c}}$ & 30 & $50.3 \pm 0.96$ \\
\hline$\geq 6$ & 31 & $26.5 \pm 0.99^{b c}$ & 28 & $40.8 \pm 1.48$ & 27 & $52.4 \pm 1.46$ & 31 & $26.0 \pm 0.92$ & 28 & $42.4 \pm 1.23^{\mathrm{a}}$ & 27 & $51.6 \pm 1.32$ \\
\hline $\begin{array}{l}\text { Dam's live } \\
\text { weight, kg }\end{array}$ & & NS & & NS & & NS & & NS & & NS & & NS \\
\hline $30.01-35.00$ & 24 & $27.6 \pm 0.93$ & 19 & $40.0 \pm 1.42$ & 18 & $52.8 \pm 1.41$ & 24 & $26.1 \pm 0.87$ & 19 & $39.5 \pm 1.19$ & 18 & $49.7 \pm 1.27$ \\
\hline $35.01-40.00$ & 10 & $28.1 \pm 1.04$ & 9 & $42.4 \pm 1.54$ & 9 & $53.6 \pm 1.52$ & 10 & $26.8 \pm 0.97$ & 9 & $41.5 \pm 1.28$ & 9 & $51.2 \pm 1.37$ \\
\hline $40.01-45.00$ & 31 & $28.1 \pm 0.87$ & 27 & $40.6 \pm 1.29$ & 26 & $52.7 \pm 1.27$ & 31 & $26.7 \pm 0.82$ & 27 & $42.9 \pm 1.07$ & 26 & $52.2 \pm 1.15$ \\
\hline $45.01-50.00$ & 39 & $28.9 \pm 0.69$ & 33 & $44.2 \pm 1.03$ & 32 & $54.2 \pm 1.02$ & 39 & $27.2 \pm 0.64$ & 33 & $42.7 \pm 0.86$ & 32 & $51.6 \pm 0.92$ \\
\hline$\geq 50.01$ & 21 & $30.2 \pm 0.98$ & 19 & $43.3 \pm 1.47$ & 19 & $52.7 \pm 1.46$ & 21 & $28.8 \pm 0.92$ & 19 & $43.2 \pm 1.23$ & 19 & $52.0 \pm 1.32$ \\
\hline Birth Type & & $* *$ & & $* *$ & & NS & & $* *$ & & $* * *$ & & NS \\
\hline Single & 73 & $30.0 \pm 0.49^{\mathrm{a}}$ & 67 & $44.5 \pm 0.72^{\mathrm{a}}$ & 66 & $54.3 \pm 0.71$ & 73 & $28.6 \pm 0.46^{\mathrm{a}}$ & 67 & $44.9 \pm 0.60^{\mathrm{a}}$ & 66 & $53.0 \pm 0.64$ \\
\hline Twin & 42 & $29.3 \pm 0.62^{\mathrm{ab}}$ & 32 & $43.1 \pm 0.96^{\mathrm{ab}}$ & 30 & $53.4 \pm 0.94$ & 42 & $28.1 \pm 0.58^{\mathrm{a}}$ & 32 & $42.1 \pm 0.80^{\mathrm{a}}$ & 30 & $51.0 \pm 0.86$ \\
\hline$\geq$ Triplets & 10 & $26.3 \pm 1.04^{\mathrm{b}}$ & 8 & $38.7 \pm 1.61^{\mathrm{a}}$ & 8 & $52.0 \pm 1.59$ & 10 & $24.6 \pm 0.98^{b}$ & 8 & $38.9 \pm 1.34^{\mathrm{b}}$ & 8 & $50.0 \pm 1.44$ \\
\hline Sex & & NS & & $*$ & & $*$ & & NS & & NS & & $\mathrm{NS}$ \\
\hline Female & 63 & $27.9 \pm 0.56$ & 53 & $40.9 \pm 0.83$ & 52 & $52.1 \pm 0.82$ & 63 & $26.9 \pm 0.53$ & 53 & $41.4 \pm 0.70$ & 52 & $51.0 \pm 0.74$ \\
\hline Male & 62 & $29.2 \pm 0.60$ & 54 & $43.3 \pm 0.89$ & 52 & $54.3 \pm 0.88$ & 62 & $27.4 \pm 0.56$ & 54 & $42.4 \pm 0.74$ & 52 & $51.7 \pm 0.80$ \\
\hline
\end{tabular}

NS: Non significant $(\mathrm{P}>0.05), *: \mathrm{P}<0.05, * *: \mathrm{P}<0.01, * * *: \mathrm{P}<0.001$.

$\mathrm{a}, \mathrm{b}, \mathrm{c}$ : Means within the same column with different superscript differ significantly $(\mathrm{P}<0.05)$. 
the rump and the sacrum heights at the Table II, the body and the chest lengths at the Table III, the chest depth and the chest circumference at the Table IV, the circumference of leg and cannon bone circumference at the Table V, the chest width and the front-rump width at the Table VI, mid-rump width at the Table VII are presented.

In the experiment, the wither height, back height, rump height, sacrum height, body length, chest length, chest depth, chest circumference, circumference of leg, cannon bone circumference, chest width, front-rump width and midrump width at birth, the ages of 60th (weaning) and 150th days were 29.8, 43.8 and $56.1 \mathrm{~cm} ; 28.4,43.8$ and $53.4 \mathrm{~cm}$; 28.7, 44.6 and $54.4 \mathrm{~cm} ; 26.2,40.6$ and 47.5 and; $28.7,43.6$ and $53.3 \mathrm{~cm} ; 17.0,22.2$ and $27.3 \mathrm{~cm} ; 13.3,19.3$ and 24.1 $\mathrm{cm} ; 30.4,51.7$ and $61.4 \mathrm{~cm} ; 26.9,41.4$ and $49.6 \mathrm{~cm} ; 5.2,6.6$ and $7.3 \mathrm{~cm} ; 5.9,9.2$ and $10.6 \mathrm{~cm} ; 6.0,9.3$ and $11.1 \mathrm{~cm} ; 8.7$, 11.3 and $13.2 \mathrm{~cm}$ at BH kids; 27.3, 40.4 and $50.3 \mathrm{~cm} ; 25.9$, 40.1 and $49.2 \mathrm{~cm} ; 29.3,42.9$ and $51.0 \mathrm{~cm} ; 25.3,37.6$ and $45.7 \mathrm{~cm} ; 27.1,40.5$ and $50.4 \mathrm{~cm} ; 15.9,22.3$ and $27.5 \mathrm{~cm}$; $12.3,18.4$ and $22.9 \mathrm{~cm} ; 29.0,48.1$ and $57.3 \mathrm{~cm} ; 21.3,36.4$ and $43.4 \mathrm{~cm} ; 5.1,6.0$ and $6.5 \mathrm{~cm} ; 5.0,7.9$ and $9.5 \mathrm{~cm} ; 5.6$, 9.1 and $10.7 \mathrm{~cm} ; 7.4,10.8$ and $11.9 \mathrm{~cm}$ at pure $\mathrm{HG}$ kids.
In this research, the effect of the genotype, mother's age, mother's weight, birth type and sex on the withers height was examined at birth, weaning and the 150th day. At birth, while the mother's weight and sex had no impact on the withers height; genotype, the mother's age and birth type had various effects $(\mathrm{P}<0.05, \mathrm{P}<0.05$ and $\mathrm{P}<0.01)$. At weaning, the mother's age and weight had no effect on the withers height. However, genotype, birth type and sex had various effects $(\mathrm{P}<0.05, \mathrm{P}<0.01$ and $\mathrm{P}<0.05)$. At the 150th day, the mother's age and weight, and the birth type had no effect but the genotype and sex were effective on various levels $(\mathrm{P}<0.001$ and $\mathrm{P}<0.05)$. At birth, while the mother's age, the mother's weight and sex had no impact on the back height; genotype and birth type had various effects $(\mathrm{P}<0.05$ and $\mathrm{P}<0.01$ ). At weaning, the weight of the mother and sex had no effect on the back height but genotype, the age of the mother and birth type had various effects $(\mathrm{P}<0.01, \mathrm{P}<0.05$ and $\mathrm{P}<0.001)$. At the 150th day, only the genotype was effective on the back height $(\mathrm{P}<0.01)$ (Table I).

In this study, at birth, while the genotype, the mother's age and sex had no impact on the rump height, the weight of the mother and birth type had various effects $(\mathrm{P}<0.05$ and

Table II. Least square means, significance and multiple comparison test results for rump and sacrum height of goats at different periods (cm).

\begin{tabular}{|c|c|c|c|c|c|c|c|c|c|c|c|c|}
\hline \multirow{3}{*}{ Factors } & \multicolumn{6}{|c|}{ Rump Height } & \multicolumn{6}{|c|}{ Sacrum Height } \\
\hline & \multicolumn{2}{|r|}{ Birth } & \multicolumn{2}{|c|}{$\begin{array}{c}60^{\text {th }} \text { day } \\
\text { (weaning) }\end{array}$} & \multicolumn{2}{|c|}{$150^{\text {th }}$ day } & \multicolumn{2}{|r|}{ Birth } & \multicolumn{2}{|c|}{$\begin{array}{l}60^{\text {th }} \text { day } \\
\text { (weaning) }\end{array}$} & \multicolumn{2}{|c|}{$150^{\text {th }}$ day } \\
\hline & $\mathrm{n}$ & Mean \pm SD & $\mathrm{n}$ & Mean \pm SD & $\mathrm{n}$ & Mean \pm SD & $\mathrm{n}$ & Mean \pm SD & $\mathrm{n}$ & Mean \pm SD & $\mathrm{n}$ & Mean \pm SD \\
\hline General & 125 & $29.2 \pm 0.42$ & 107 & $45.2 \pm 0.58$ & 104 & $51.1 \pm 0.59$ & 125 & $26.3 \pm 0.35$ & 107 & $39.9 \pm 0.47$ & 104 & $46.9 \pm 0.43$ \\
\hline Genotype & & NS & & NS & & NS & & NS & & $*$ & & $*$ \\
\hline $\mathrm{BH}$ & 80 & $28.7 \pm 0.65$ & 68 & $44.6 \pm 0.73$ & 66 & $54.4 \pm 0.86$ & 80 & $26.2 \pm 0.59$ & 68 & $40.6 \pm 0.69$ & 66 & $47.5 \pm 0.76$ \\
\hline HG & 45 & $29.3 \pm 0.89$ & 39 & $42.9 \pm 0.98$ & 38 & $51.0 \pm 1.15$ & 45 & $25.3 \pm 0.80$ & 39 & $37.6 \pm 0.93$ & 38 & $45.7 \pm 1.03$ \\
\hline Dame Age & & NS & & NS & & NS & & NS & & NS & & NS \\
\hline 2 & 19 & $27.7 \pm 0.98$ & 15 & $43.8 \pm 1.14$ & 15 & $53.4 \pm 1.33$ & 19 & $24.7 \pm 0.89$ & 15 & $39.0 \pm 1.08$ & 15 & $46.3 \pm 1.19$ \\
\hline 3 & 18 & $31.1 \pm 1.34$ & 13 & $45.5 \pm 1.42$ & 12 & $52.6 \pm 1.68$ & 18 & $26.7 \pm 1.21$ & 13 & $39.5 \pm 1.35$ & 12 & $46.6 \pm 1.49$ \\
\hline 4 & 22 & $30.1 \pm 1.17$ & 20 & $44.1 \pm 1.37$ & 20 & $53.2 \pm 1.60$ & 22 & $25.9 \pm 1.08$ & 20 & $39.9 \pm 1.34$ & 20 & $47.3 \pm 1.48$ \\
\hline 5 & 35 & $27.7 \pm 0.82$ & 31 & $42.0 \pm 0.93$ & 30 & $52.2 \pm 1.09$ & 35 & $25.6 \pm 0.74$ & 31 & $36.9 \pm 0.87$ & 30 & $46.2 \pm 0.97$ \\
\hline$\geq 6$ & 31 & $28.2 \pm 1.10$ & 28 & $43.3 \pm 1.27$ & 27 & $52.0 \pm 1.50$ & 31 & $25.8 \pm 0.99$ & 28 & $40.0 \pm 1.20$ & 27 & $46.7 \pm 1.33$ \\
\hline $\begin{array}{l}\text { Dam's live weight, } \\
\mathrm{kg}\end{array}$ & & $*$ & & $*$ & & NS & & NS & & NS & & $\mathrm{NS}$ \\
\hline $30.01-35.00$ & 24 & $26.4 \pm 1.04^{\mathrm{b}}$ & 19 & $40.3 \pm 1.22^{\mathrm{b}}$ & 18 & $50.5 \pm 1.44$ & 24 & $25.3 \pm 0.94$ & 19 & $38.0 \pm 1.16$ & 18 & $45.8 \pm 1.28$ \\
\hline $35.01-40.00$ & 10 & $28.1 \pm 1.15^{\mathrm{a}}$ & 9 & $43.0 \pm 1.32^{\mathrm{a}}$ & 9 & $52.9 \pm 1.55$ & 10 & $25.4 \pm 1.04$ & 9 & $38.7 \pm 1.24$ & 9 & $45.0 \pm 1.38$ \\
\hline $40.01-45.00$ & 31 & $28.3 \pm 0.97^{\mathrm{b}}$ & 27 & $43.9 \pm 1.11^{\mathrm{a}}$ & 26 & $53.5 \pm 1.30$ & 31 & $25.2 \pm 0.88$ & 27 & $39.8 \pm 1.04$ & 26 & $47.3 \pm 1.16$ \\
\hline $45.01-50.00$ & 39 & $30.4 \pm 0.77^{\mathrm{a}}$ & 33 & $45.6 \pm 0.89^{\mathrm{a}}$ & 32 & $53.0 \pm 1.04$ & 39 & $25.9 \pm 0.70$ & 33 & $39.0 \pm 0.84$ & 32 & $46.3 \pm 0.94$ \\
\hline$\geq 50.01$ & 21 & $31.6 \pm 1.09^{\mathrm{a}}$ & 19 & $45.8 \pm 1.27^{\mathrm{a}}$ & 19 & $53.6 \pm 1.49$ & 21 & $26.8 \pm 0.99$ & 19 & $39.8 \pm 1.20$ & 19 & $47.6 \pm 1.32$ \\
\hline Birth Type & & $* *$ & & $* * *$ & & $*$ & & $* *$ & & $* *$ & & NS \\
\hline Single & 73 & $30.8 \pm 0.55^{\mathrm{a}}$ & 67 & $47.6 \pm 0.62^{a}$ & 66 & $54.8 \pm 0.72^{\mathrm{a}}$ & 73 & $27.6 \pm 0.49^{\mathrm{a}}$ & 67 & $41.3 \pm 0.58^{\mathrm{a}}$ & 66 & $47.6 \pm 0.64$ \\
\hline Twin & 42 & $29.6 \pm 0.69^{\mathrm{ab}}$ & 32 & $44.1 \pm 0.82^{b}$ & 30 & $52.1 \pm 0.97^{\mathrm{b}}$ & 42 & $25.7 \pm 0.64^{b}$ & 32 & $39.1 \pm 0.82^{\mathrm{ab}}$ & 30 & $45.7 \pm 0.90$ \\
\hline$\geq$ Triplets & 10 & $26.5 \pm 1.16^{\mathrm{b}}$ & 8 & $39.4 \pm 1.38^{\mathrm{c}}$ & 8 & $51.2 \pm 1.63^{\mathrm{b}}$ & 10 & $23.9 \pm 1.05^{\mathrm{b}}$ & 8 & $36.9 \pm 1.31^{\mathrm{b}}$ & 8 & $46.4 \pm 1.44$ \\
\hline Sex & & NS & & $* *$ & & NS & & NS & & NS & & NS \\
\hline Female & 63 & $28.4 \pm 0.62$ & 53 & $42.5 \pm 0.72$ & 52 & $52.0 \pm 0.84$ & 63 & $25.4 \pm 0.57$ & 53 & $38.5 \pm 0.68$ & 52 & $46.3 \pm 0.75$ \\
\hline Male & 62 & $29.4 \pm 0.66$ & 54 & $44.9 \pm 0.77$ & 52 & $53.4 \pm 0.90$ & 62 & $26.1 \pm 0.60$ & 54 & $39.6 \pm 0.73$ & 52 & $46.9 \pm 0.80$ \\
\hline
\end{tabular}

NS: Non significant $(\mathrm{P}>0.05),{ }^{*}: \mathrm{P}<0.05, * *: \mathrm{P}<0.01, * * *: \mathrm{P}<0.001$.

a, b, c: Means within the same column with different superscript differ significantly $(\mathrm{P}<0.05)$. 
Table III. Least square means, significance and multiple comparison test results for body and chest length of goats at different periods (cm).

\begin{tabular}{|c|c|c|c|c|c|c|c|c|c|c|c|c|}
\hline \multirow{3}{*}{ Factors } & \multicolumn{6}{|c|}{ Body Length } & \multicolumn{6}{|c|}{ Chest length } \\
\hline & \multicolumn{2}{|r|}{ Birth } & \multicolumn{2}{|c|}{$\begin{array}{l}60 \mathrm{t}^{\mathrm{h}} \text { day } \\
\text { (weaning) }\end{array}$} & \multicolumn{2}{|c|}{$150^{\text {th }}$ day } & \multicolumn{2}{|r|}{ Birth } & \multicolumn{2}{|c|}{$\begin{array}{l}60 \mathrm{t}^{\mathrm{h}} \text { day } \\
\text { (weaning) }\end{array}$} & \multicolumn{2}{|r|}{$150 \mathrm{t}^{\mathrm{h}}$ day } \\
\hline & $\mathrm{n}$ & Mean \pm SD & $\mathrm{n}$ & Mean \pm SD & $\mathrm{n}$ & Mean \pm SD & $\mathrm{n}$ & Mean \pm SD & $\mathrm{n}$ & Mean \pm SD & $\mathrm{n}$ & Mean \pm SD \\
\hline General & 125 & $29.0 \pm 0.41$ & 107 & $44.3 \pm 0.53$ & 104 & $53.8 \pm 0.54$ & 125 & $17.1 \pm 0.26$ & 107 & $23.3 \pm 0.32$ & 104 & $28.3 \pm 0.31$ \\
\hline Genotype & & NS & & ** & & $*$ & & NS & & NS & & NS \\
\hline $\mathrm{BH}$ & 80 & $28.7 \pm 0.59$ & 68 & $43.6 \pm 0.64$ & 66 & $53.3 \pm 0.81$ & 80 & $17.0 \pm 0.44$ & 68 & $22.2 \pm 0.47$ & 66 & $27.3 \pm 0.44$ \\
\hline $\mathrm{HG}$ & 45 & $27.1 \pm 0.80$ & 39 & $40.5 \pm 0.87$ & 38 & $50.4 \pm 1.10$ & 45 & $15.9 \pm 0.59$ & 39 & $22.3 \pm 0.64$ & 38 & $27.5 \pm 0.59$ \\
\hline Dame Age & & $*$ & & NS & & NS & & NS & & NS & & NS \\
\hline 2 & 19 & $27.3 \pm 0.89^{c}$ & 15 & $43.2 \pm 1.01$ & 15 & $52.2 \pm 1.27$ & 19 & $16.7 \pm 0.66$ & 15 & $21.9 \pm 0.74$ & 15 & $26.7 \pm 0.68$ \\
\hline 3 & 18 & $30.9 \pm 1.21^{\mathrm{a}}$ & 13 & $42.7 \pm 1.27$ & 12 & $52.2 \pm 1.60$ & 18 & $17.0 \pm 0.89$ & 13 & $23.4 \pm 0.93$ & 12 & $28.0 \pm 0.85$ \\
\hline 4 & 22 & $27.9 \pm 1.06^{\mathrm{b}}$ & 20 & $42.2 \pm 1.19$ & 20 & $51.8 \pm 1.51$ & 22 & $15.2 \pm 0.78$ & 20 & $21.1 \pm 0.89$ & 20 & $26.5 \pm 0.81$ \\
\hline 5 & 35 & $27.3 \pm 0.74 \mathrm{~b}^{\mathrm{c}}$ & 31 & $40.6 \pm 0.82$ & 30 & $51.4 \pm 1.04$ & 35 & $17.0 \pm 0.54$ & 31 & $22.2 \pm 0.60$ & 30 & $27.5 \pm 0.55$ \\
\hline$\geq 6$ & 31 & $26.0 \pm 0.99^{\mathrm{abc}}$ & 28 & $41.6 \pm 1.12$ & 27 & $51.4 \pm 1.42$ & 31 & $16.4 \pm 0.74$ & 28 & $22.6 \pm 0.83$ & 27 & $28.4 \pm 0.76$ \\
\hline $\begin{array}{l}\text { Dam's live } \\
\text { weight, } \mathrm{kg}\end{array}$ & & $*$ & & NS & & NS & & NS & & NS & & $*$ \\
\hline $30.01-35.00$ & 24 & $26.3 \pm 0.93 b$ & 19 & $40.4 \pm 1.09$ & 18 & $50.5 \pm 1.37$ & 24 & $15.7 \pm 0.69$ & 19 & $21.0 \pm 0.80$ & 18 & $26.2 \pm 0.73 \mathrm{c}$ \\
\hline $35.01-40.00$ & 10 & $27.2 \pm 1.04 \mathrm{a}^{\mathrm{b}}$ & 9 & $40.2 \pm 1.17$ & 9 & $49.7 \pm 1.48$ & 10 & $17.8 \pm 0.77$ & 9 & $21.4 \pm 0.86$ & 9 & $26.4 \pm 0.79^{b c}$ \\
\hline $40.01-45.00$ & 31 & $26.8 \pm 0.88 \mathrm{a}^{\mathrm{b}}$ & 27 & $42.2 \pm 0.98$ & 26 & $51.1 \pm 1.24$ & 31 & $16.4 \pm 0.65$ & 27 & $21.6 \pm 0.72$ & 26 & $27.2 \pm 0.66 \mathrm{a}^{\mathrm{bc}}$ \\
\hline $45.01-50.00$ & 39 & $28.9 \pm 0.69 \mathrm{a}^{\mathrm{b}}$ & 33 & $43.9 \pm 0.77$ & 32 & $53.7 \pm 0.98$ & 39 & $16.5 \pm 0.51$ & 33 & $23.6 \pm 0.58$ & 32 & $29.2 \pm 0.53 \mathrm{a}$ \\
\hline$\geq 50.01$ & 21 & $30.3 \pm 0.99^{\mathrm{a}}$ & 19 & $43.6 \pm 1.12$ & 19 & $54.1 \pm 1.42$ & 21 & $16.0 \pm 0.73$ & 19 & $23.6 \pm 0.83$ & 19 & $28.2 \pm 0.76^{\mathrm{ab}}$ \\
\hline Birth Type & & $* * *$ & & $* * *$ & & $* * *$ & & $* *$ & & $* * *$ & & $* * *$ \\
\hline Single & 73 & $30.6 \pm 0.49^{\mathrm{a}}$ & 67 & $46.4 \pm 0.54^{\mathrm{a}}$ & 66 & $55.0 \pm 0.68 \mathrm{a}$ & 73 & $17.9 \pm 0.37 \mathrm{a}$ & 67 & $24.4 \pm 0.40^{\mathrm{a}}$ & 66 & $29.0 \pm 0.37 \mathrm{a}$ \\
\hline Twin & 42 & $29.0 \pm 0.62 b$ & 32 & $42.4 \pm 0.73 b$ & 30 & $52.7 \pm 0.92^{\mathrm{ab}}$ & 42 & $16.2 \pm 0.46 \mathrm{~b}$ & 32 & $22.9 \pm 0.54^{\mathrm{a}}$ & 30 & $28.3 \pm 0.49 \mathrm{a}$ \\
\hline$\geq$ Triplets & 10 & $24.1 \pm 1.04^{\mathrm{c}}$ & 8 & $37.4 \pm 1.23^{\mathrm{c}}$ & 8 & $47.7 \pm 1.54 \mathrm{~b}$ & 10 & $15.3 \pm 0.78 \mathrm{~b}$ & 8 & $19.4 \pm 0.90^{\mathrm{b}}$ & 8 & $25.0 \pm 0.82 \mathrm{~b}$ \\
\hline$\overline{S e x}$ & & NS & & $*$ & & $*$ & & NS & & NS & & $*$ \\
\hline Female & 63 & $27.4 \pm 0.56$ & 53 & $41.3 \pm 0.63$ & 52 & $50.9 \pm 0.80$ & 63 & $16.2 \pm 0.42$ & 53 & $21.9 \pm 0.47$ & 52 & $26.9 \pm 0.43$ \\
\hline Male & 62 & $28.4 \pm 0.60$ & 54 & $42.8 \pm 0.68$ & 52 & $52.7 \pm 0.86$ & 62 & $16.8 \pm 0.44$ & 54 & $22.6 \pm 0.50$ & 52 & $28.0 \pm 0.46$ \\
\hline
\end{tabular}

NS: Non significant $(\mathrm{P}>0.05), *: \mathrm{P}<0.05, * *: \mathrm{P}<0.01, * * *: \mathrm{P}<0.001$.

$\mathrm{a}, \mathrm{b}, \mathrm{c}$ : Means within the same column with different superscript differ significantly $(\mathrm{P}<0.05)$.

$\mathrm{P}<0.01)$. At weaning, the genotype and age of the mother had no effect on the rump height however, the weight of the mother, birth type and sex had various effects $(\mathrm{P}<0.05, \mathrm{P}<0.001$ and $\mathrm{P}<0.01)$. At the 150th day, only the birth type was effective on the rump height $(\mathrm{P}<0.05)$. At birth, only the birth type was effective $(\mathrm{P}<0.01)$. At weaning, the age of the mother, the weight of the mother and the sex had no effect on the sacrum height. However, the genotype and birth type had various effects $(\mathrm{P}<0.05$ and $\mathrm{P}<0.01)$. At the 150th day, only genotype was effective on the sacrum height $(\mathrm{P}<0.05)$ (Table II).

In this research, at birth, genotype and sex were ineffective on the body length. However, the age of the mother, the weight of the mother and the birth type had various effects $(\mathrm{P}<0.05, \mathrm{P}<0.05$ and $\mathrm{P}<0.001)$. At weaning, the age of the mother, the weight of the mother had no effect on the body length. However, the genotype, birth type and sex had various effects $(\mathrm{P}<0.01, \mathrm{P}<0.001$ and $\mathrm{P}<0.05)$. At the 180th day, the age of the mother and the weight of the mother were ineffective. However, the genotype, birth type and sex had various effects $(\mathrm{P}<0.05, \mathrm{P}<0.05$ and $\mathrm{P}<0.001)$. At birth and weaning, only the birth type was effective
$(\mathrm{P}<0.01$ and $\mathrm{P}<0.001)$. At the 150th day, the genotype and the age of the mother had no effects. However, the weight of the mother, the birth type and the sex had various effects $(\mathrm{P}<0.05, \mathrm{P}<0.001$ and $\mathrm{P}<0.05)$ (Table III).

In this study, at birth, only the birth type was effective $(\mathrm{P}<0.05)$. At weaning, the genotype and the weight of the mother were ineffective. However, the weight of the mother, the birth type and the sex was effective on various levels $(\mathrm{P}<0.001, \mathrm{P}<0.001$ and $\mathrm{P}<0.05)$. At the 180th day, the genotype, the age and weight of the mother were ineffective. However, the birth type and sex had similar effects $(\mathrm{P}<0.01)$. At birth, the genotype, the mother's age and the weight of the mother had no impact on the heart girth. However, the birth type and sex were effective on various levels $(\mathrm{P}<0.001$ and $\mathrm{P}<0.01)$. At weaning, the age of the mother was ineffective. However, the genotype, the weight of the mother, the birth type and sex had various effects $(\mathrm{P}<0.01, \mathrm{P}<0.01, \mathrm{P}<0.001$ and $\mathrm{P}<0.05)$. At the 150th day, all of the factors were effective on various levels with the exception of the age of the mother $(\mathrm{P}<0.05$ and $\mathrm{P}<0.01)$ (Table IV). 
Table IV. Least square means, significance and multiple comparison test results for chest depth and chest circumference of goats at different periods $(\mathrm{cm})$.

\begin{tabular}{|c|c|c|c|c|c|c|c|c|c|c|c|c|}
\hline \multirow{3}{*}{ Factors } & \multicolumn{6}{|c|}{ Chest depth } & \multicolumn{6}{|c|}{ Chest cir cumference } \\
\hline & \multicolumn{2}{|r|}{ Birth } & \multicolumn{2}{|c|}{$\begin{array}{l}60 \mathrm{t}^{\mathrm{h}} \text { day } \\
\text { (weaning) }\end{array}$} & \multicolumn{2}{|c|}{$150 \mathrm{t}^{\mathrm{h}}$ day } & \multicolumn{2}{|r|}{ Birth } & \multicolumn{2}{|c|}{$\begin{array}{l}60^{\text {th }} \text { day } \\
\text { (weaning) }\end{array}$} & \multicolumn{2}{|c|}{$150 \mathrm{t}^{\mathrm{h}}$ day } \\
\hline & $\mathrm{n}$ & Mean \pm SD & $\mathrm{n}$ & Mean \pm SD & $\mathrm{n}$ & Mean \pm SD & $\mathrm{n}$ & Mean \pm SD & $\mathrm{n}$ & Mean \pm SD & $\mathrm{n}$ & Mean \pm SD \\
\hline $\begin{array}{l}\text { General } \\
\text { Genotype }\end{array}$ & 125 & $\begin{array}{c}13.2 \pm 0.17 \\
\text { NS }\end{array}$ & 107 & $\begin{array}{c}19.7 \pm 0.23 \\
\mathrm{NS}\end{array}$ & 104 & $\begin{array}{c}24.2 \pm 0.23 \\
\text { NS }\end{array}$ & 125 & $\begin{array}{c}31.1 \pm 0.49 \\
\text { NS }\end{array}$ & 107 & $\begin{array}{c}52.3 \pm 0.60 \\
* *\end{array}$ & 104 & $\begin{array}{c}61.3 \pm 0.63 \\
* *\end{array}$ \\
\hline $\mathrm{BH}$ & 80 & $13.3 \pm 0.29$ & 68 & $19.3 \pm 0.28$ & 66 & $24.1 \pm 0.34$ & 80 & $30.4 \pm 0.70$ & 68 & $51.7 \pm 0.70$ & 66 & $61.4 \pm 0.88$ \\
\hline $\mathrm{HG}$ & 45 & $12.3 \pm 0.40$ & 39 & $18.4 \pm 0.37$ & 38 & $22.9 \pm 0.46$ & 45 & $29.0 \pm 0.95$ & 39 & $48.1 \pm 0.94$ & 38 & $57.3 \pm 1.19$ \\
\hline Dame Age & & NS & & NS & & NS & & NS & & NS & & NS \\
\hline 2 & 19 & $13.0 \pm 0.44$ & 15 & $19.4 \pm 0.43$ & 15 & $23.8 \pm 0.53$ & 19 & $29.5 \pm 1.06$ & 15 & $52.3 \pm 1.09$ & 15 & $62.0 \pm 1.38$ \\
\hline 3 & 18 & $13.4 \pm 0.60$ & 13 & $19.0 \pm 0.54$ & 12 & $23.4 \pm 0.67$ & 18 & $30.8 \pm 1.44$ & 13 & $50.3 \pm 1.38$ & 12 & $58.4 \pm 1.73$ \\
\hline 4 & 22 & $12.7 \pm 0.53$ & 20 & $18.9 \pm 0.52$ & 20 & $23.7 \pm 0.64$ & 22 & $29.8 \pm 1.26$ & 20 & $48.7 \pm 1.31$ & 20 & $58.3 \pm 1.66$ \\
\hline 5 & 35 & $12.4 \pm 0.37$ & 31 & $18.3 \pm 0.35$ & 30 & $23.4 \pm 0.43$ & 35 & $28.8 \pm 0.88$ & 31 & $48.4 \pm 0.89$ & 30 & $58.2 \pm 1.13$ \\
\hline$\geq 6$ & 31 & $12.6 \pm 0.49$ & 28 & $18.6 \pm 0.48$ & 27 & $23.0 \pm 0.59$ & 31 & $29.8 \pm 1.18$ & 28 & $49.9 \pm 1.22$ & 27 & $59.7 \pm 1.54$ \\
\hline $\begin{array}{l}\text { Dam's live } \\
\text { weight, } \mathrm{kg}\end{array}$ & & NS & & $* * *$ & & NS & & NS & & $* *$ & & $*$ \\
\hline $30.01-35.00$ & 24 & $12.6 \pm 0.47$ & 19 & $17.8 \pm 0.46 \mathrm{c}$ & 18 & $22.6 \pm 0.57$ & 24 & $28.0 \pm 1.11$ & 19 & $46.0 \pm 1.18^{\mathrm{b}}$ & 18 & $55.5 \pm 1.48 \mathrm{~b}$ \\
\hline $35.01-40.00$ & 10 & $12.9 \pm 0.52$ & 9 & $18.1 \pm 0.50 \mathrm{a}^{\mathrm{bc}}$ & 9 & $24.0 \pm 0.62$ & 10 & $29.2 \pm 1.24$ & 9 & $49.3 \pm 1.27 \mathrm{a}$ & 9 & $59.0 \pm 1.60^{\mathrm{a}}$ \\
\hline $40.01-45.00$ & 31 & $12.7 \pm 0.44$ & 27 & $18.4 \pm 0.42^{\mathrm{bc}}$ & 26 & $23.1 \pm 0.52$ & 31 & $29.4 \pm 1.04$ & 27 & $50.2 \pm 1.07 \mathrm{a}$ & 26 & $60.0 \pm 1.34^{\mathrm{a}}$ \\
\hline $45.01-50.00$ & 39 & $13.2 \pm 0.34$ & 33 & $20.1 \pm 0.34 \mathrm{a}$ & 32 & $24.0 \pm 0.42$ & 39 & $31.7 \pm 0.83$ & 33 & $52.4 \pm 0.86 \mathrm{a}$ & 32 & $61.7 \pm 1.08^{\mathrm{a}}$ \\
\hline $\begin{array}{l}\geq 50.01 \\
\text { Birth Type }\end{array}$ & 21 & $\begin{array}{c}12.8 \pm 0.49 \\
*\end{array}$ & 19 & $\begin{array}{c}19.9 \pm 0.48^{\mathrm{ab}} \\
* * *\end{array}$ & 19 & $\begin{array}{c}23.9 \pm 0.59 \\
* *\end{array}$ & 21 & $\begin{array}{l}30.4 \pm 1.18 \\
* * *\end{array}$ & 19 & $\begin{array}{c}51.7 \pm 1.22 \mathrm{a} \\
* * *\end{array}$ & 19 & $\begin{array}{c}60.4 \pm 1.54^{\mathrm{a}} \\
* *\end{array}$ \\
\hline Single & 73 & $13.6 \pm 0.24^{\mathrm{a}}$ & 67 & $20.5 \pm 0.23 \mathrm{a}$ & 66 & $24.6 \pm 0.29 \mathrm{a}$ & 73 & $33.0 \pm 0.59^{\mathrm{a}}$ & 67 & $54.8 \pm 0.59 \mathrm{a}$ & 66 & $62.6 \pm 0.74^{\mathrm{a}}$ \\
\hline Twin & 42 & $13.0 \pm 0.31 \mathrm{a}^{\mathrm{b}}$ & 32 & $19.0 \pm 0.31 \mathrm{~b}$ & 30 & $23.9 \pm 0.38^{\mathrm{ab}}$ & 42 & $30.0 \pm 0.74^{\mathrm{b}}$ & 32 & $49.7 \pm 0.79^{b}$ & 30 & $58.7 \pm 1.00 \mathrm{a}^{\mathrm{b}}$ \\
\hline$\geq$ Triplets & 10 & $11.9 \pm 0.52 \mathrm{~b}$ & 8 & $17.1 \pm 0.52 \mathrm{~b}$ & 8 & $21.9 \pm 0.64 b$ & 10 & $26.2 \pm 1.25^{\mathrm{b}}$ & 8 & $45.3 \pm 1.33^{b}$ & 8 & $56.7 \pm 1.68 \mathrm{~b}$ \\
\hline Sex & & NS & & $* *$ & & $* *$ & & $* *$ & & $*$ & & $*$ \\
\hline Female & 63 & $12.6 \pm 0.28$ & 55 & $18.3 \pm 0.27$ & 52 & $22.8 \pm 0.33$ & 63 & $28.6 \pm 0.67$ & 53 & $48.8 \pm 0.69$ & 52 & $58.1 \pm 0.87$ \\
\hline Male & 62 & $13.1 \pm 0.30$ & 57 & $19.4 \pm 0.29$ & 52 & $24.2 \pm 0.36$ & 62 & $31.0 \pm 0.71$ & 54 & $51.0 \pm 0.74$ & 52 & $60.5 \pm 0.93$ \\
\hline
\end{tabular}

NS: Non significant $(\mathrm{P}>0.05), *: \mathrm{P}<0.05, * *: \mathrm{P}<0.01, * * *: \mathrm{P}<0.001$

$\mathrm{a}, \mathrm{b}, \mathrm{c}$ : Means within the same column with different superscript differ significantly $(\mathrm{P}<0.05)$.

In this research, at birth, the mother's age and sex had no impact. However, the genotype, the weight of the mother and the birth type had various effects $(\mathrm{P}<0.001$, $\mathrm{P}<0.05$ and $\mathrm{P}<0.001$ ). At weaning, all of the factors were effective on various levels with the exception of $\operatorname{sex}(\mathrm{P}<0.05$ and $\mathrm{P}<0.001)$. At the 150th day, the age of the mother, the weight of the mother and the sex had no impact. However, the genotype and birth type had various effects on the leg girth $(\mathrm{P}<0.01$ and $\mathrm{P}<0.01)$. At birth, the genotype, the mother's age and the weight of the mother had no impact. However,the birth type and sex had various effects $(\mathrm{P}<0.001$ and $\mathrm{P}<0.01)$. At weaning, the age of the mother and the weight of the mother had no effects. However, the genotype, birth type and sex had various effects $(\mathrm{P}<0.001, \mathrm{P}<0.01$ and $\mathrm{P}<0.01)$. At the 150th day, the age and weight of the mother were ineffective. However, the genotype, birth type and sex had various effects $(\mathrm{P}<0.001$, $\mathrm{P}<0.05$ and $\mathrm{P}<0.05)($ Table $\mathrm{V})$.

In this study, at birth, while the mother's age and the mother's weight had no impact, the genotype, birth type and sex had various effects $(\mathrm{P}<0.05, \mathrm{P}<0.001$ and $\mathrm{P}<0.05)$. At weaning, only the genotype was effective $(\mathrm{P}<0.001)$. At the 150th day, the age of the mother, the weight of the mother and the sex were ineffective. However, the genotype and birth type had various effects $(\mathrm{P}<0.01$ and $\mathrm{P}<0.001)$. At birth, the genotype, the mother's age and the mother weight had no impact. However, the birth type and sex had various effects $(\mathrm{P}<0.001$ and $\mathrm{P}<0.05)$. At weaning, the genotype and age of the mother had no effect however, the weight of the mother, birth type and sex had various effects $(\mathrm{P}<0.01$, $\mathrm{P}<0.001$ and $\mathrm{P}<0.05)$. At the 150th day, only the birth type was effective $(\mathrm{P}<0.001)$ (Table VI).

In this research, at birth, the mother's age, the mother's weight and sex had no impact. However, the genotype and birth type had various effects $(\mathrm{P}<0.001$ and $\mathrm{P}<0.05)$. At weaning, while the genotype and the age of the mother and the birth type had no effect. However, the weight of the mother, the birth type and sex had various effects $(\mathrm{P}<0.05, \mathrm{P}<0.001$ and $\mathrm{P}<0.05)$. At the 150th day, the genotype, the weight of the mother, the birth type and sex had various effects with the exception of the age of the mother $(\mathrm{P}<0.01, \mathrm{P}<0.001, \mathrm{P}<0.001$ and $\mathrm{P}<0.05)$ (Table VII) 
Table V. Least square means, significance and multiple comparison test results for circumference of leg and cannon bone circumference of goats at different periods $(\mathrm{cm})$.

\begin{tabular}{|c|c|c|c|c|c|c|c|c|c|c|c|c|}
\hline \multirow{3}{*}{ Factors } & \multicolumn{6}{|c|}{ Circumference of leg } & \multicolumn{6}{|c|}{ Cannon bone circumference } \\
\hline & \multicolumn{2}{|r|}{ Birth } & \multicolumn{2}{|c|}{$\begin{array}{l}60 \mathrm{t}^{\mathrm{h}} \text { day } \\
\text { (weaning) }\end{array}$} & \multicolumn{2}{|r|}{$150^{\text {th }}$ day } & \multicolumn{2}{|r|}{ Birth } & \multicolumn{2}{|c|}{$\begin{array}{l}60^{\text {th }} \text { day } \\
\text { (weaning) }\end{array}$} & \multicolumn{2}{|c|}{$150 \mathrm{t}^{\mathrm{h}}$ day } \\
\hline & $\mathrm{n}$ & Mean \pm SD & $\mathrm{n}$ & Mean \pm SD & $\mathrm{n}$ & Mean \pm SD & $\mathrm{n}$ & Mean \pm SD & $\mathrm{n}$ & Mean \pm SD & $\mathrm{n}$ & Mean \pm SD \\
\hline General & 125 & $26.9 \pm 0.57$ & 107 & $41.4 \pm 0.55$ & 104 & $50.0 \pm 0.57$ & 125 & $5.3 \pm 0.07$ & 107 & $6.5 \pm 0.08$ & 104 & $7.1 \pm 0.07$ \\
\hline Genotype & & $* * *$ & & $* * *$ & & $* *$ & & NS & & $* * *$ & & $* * *$ \\
\hline $\mathrm{BH}$ & 80 & $26.9 \pm 0.76$ & 68 & $41.4 \pm 0.64$ & 66 & $49.6 \pm 0.84$ & 80 & $5.2 \pm 0.11$ & 68 & $6.6 \pm 0.10$ & 66 & $7.3 \pm 0.09$ \\
\hline HG & 45 & $21.3 \pm 1.03$ & 39 & $36.4 \pm 0$. & 38 & $43.4 \pm 1.14$ & 45 & $5.1 \pm 0.16$ & 39 & $6.0 \pm 0.13$ & 38 & $6.5 \pm 0.12$ \\
\hline Dame Age & & NS & & $*$ & & $\mathrm{NS}$ & & $\mathrm{NS}$ & & $\mathrm{NS}$ & & NS \\
\hline 2 & 19 & $25.2 \pm 1.14$ & 15 & $41.4 \pm 1.00^{\mathrm{cd}}$ & 15 & $48.7 \pm 1.32$ & 19 & $5.1 \pm 0.17$ & 15 & $6.3 \pm 0.14$ & 15 & $7.1 \pm 0.14$ \\
\hline 3 & 18 & $25.2 \pm 1.55$ & 13 & $37.6 \pm 1.26^{\mathrm{d}}$ & 12 & $45.8 \pm 1.66$ & 18 & $5.2 \pm 0.24$ & 13 & $6.1 \pm 0.19$ & 12 & $6.6 \pm 0.19$ \\
\hline 4 & 22 & $22.4 \pm 1.36$ & 20 & $37.7 \pm 1.21^{\mathrm{ab}}$ & 20 & $48.6 \pm 1.59$ & 22 & $5.3 \pm 0.21$ & 20 & $6.4 \pm 0.18$ & 20 & $6.9 \pm 0.18$ \\
\hline 5 & 35 & $23.7 \pm 0.94$ & 31 & $37.6 \pm 0.82^{b c}$ & 30 & $48.2 \pm 1.08$ & 35 & $5.1 \pm 0.14$ & 31 & $6.3 \pm 0.12$ & 30 & $6.9 \pm 0.12$ \\
\hline$\geq 6$ & 31 & $24.1 \pm 1.28$ & 28 & $40.3 \pm 1.12 \mathrm{a}$ & 27 & $48.7 \pm 1.48$ & 31 & $5.1 \pm 0.19$ & 28 & $6.3 \pm 0.17$ & 27 & $7.0 \pm 0.16$ \\
\hline $\begin{array}{l}\text { Dam's live } \\
\text { weight, kg }\end{array}$ & & $*$ & & $*$ & & NS & & NS & & $\mathrm{N}$ & & NS \\
\hline $30.01-35.00$ & 24 & $21.6 \pm 1.20^{\mathrm{b}}$ & 19 & $36.4 \pm 1.0$ & 18 & $46.1 \pm 1.42$ & 24 & $5.0 \pm 0.18$ & 19 & $6.2 \pm 0.16$ & 18 & $6.8 \pm 0.16$ \\
\hline $35.01-40.00$ & 10 & $24.5 \pm 1.34^{\mathrm{a}}$ & 9 & $36.8 \pm 1.17^{\mathrm{bc}}$ & 9 & $46.4 \pm 1.54$ & 10 & $5.0 \pm 0.20$ & 9 & $6.2 \pm 0.17$ & 9 & $6.9 \pm 0.17$ \\
\hline $40.01-45.00$ & 31 & $23.7 \pm 1.13^{\mathrm{a}}$ & 27 & $39.8 \pm 0.98^{\mathrm{ab}}$ & 26 & $48.7 \pm 1.29$ & 31 & $5.0 \pm 0.17$ & 27 & $6.2 \pm 0.14$ & 26 & $6.8 \pm 0.14$ \\
\hline $45.01-50.00$ & 39 & $26.0 \pm 0.89^{\mathrm{a}}$ & 33 & $40.9 \pm 0.79 a$ & 32 & $48.7 \pm 1.03$ & 39 & $5.3 \pm 0.14$ & 33 & $6.3 \pm 0.12$ & 32 & $6.8 \pm 0.12$ \\
\hline$\geq 50.01$ & 21 & $24.7 \pm 1.27^{\mathrm{a}}$ & 19 & $40.8 \pm 1.12 \mathrm{a}$ & 19 & $50.1 \pm 1.47$ & 21 & $5.4 \pm 0.19$ & 19 & $6.6 \pm 0.17$ & 19 & $7.1 \pm 0.16$ \\
\hline Birth Type & & $* * *$ & & $* * *$ & & $* *$ & & $* * *$ & & $* *$ & & * \\
\hline Single & 73 & $28.2 \pm 0.63^{\mathrm{a}}$ & 67 & $43.0 \pm 0.54 \mathrm{a}$ & 66 & $51.1 \pm 0.72^{\mathrm{a}}$ & 73 & $5.6 \pm 0.10^{\mathrm{a}}$ & 67 & $6.6 \pm 0.08 \mathrm{a}$ & 66 & $7.1 \pm 0.08^{\mathrm{a}}$ \\
\hline Twin & 42 & $25.4 \pm 0.80^{\mathrm{b}}$ & 32 & $38.5 \pm 0.73^{b}$ & 30 & $48.4 \pm 0.96^{\mathrm{a}}$ & 42 & $5.2 \pm 0.12^{\mathrm{b}}$ & 32 & $6.3 \pm 0.11^{\mathrm{b}}$ & 30 & $6.8 \pm 0.11^{\mathrm{b}}$ \\
\hline$\geq$ Triplets & 10 & $18.6 \pm 1.35^{\mathrm{c}}$ & 8 & $35.3 \pm 1.22^{\mathrm{b}}$ & 8 & $44.4 \pm 1.61 \mathrm{~b}$ & 10 & $4.7 \pm 0.21^{\mathrm{b}}$ & 8 & $6.0 \pm 0.18^{\mathrm{b}}$ & 8 & $6.8 \pm 0.18$ \\
\hline $\operatorname{Sex}$ & & NS & & NS & & NS & & $* *$ & & $* *$ & & $*$ \\
\hline Femal & 63 & $23.9 \pm 0.73$ & 53 & $38.7 \pm 0.63$ & 5 & $47.4 \pm 0.83$ & 63 & $5.0 \pm 0.11$ & 53 & $6.1 \pm 0.09$ & 52 & $6.7 \pm 0.09$ \\
\hline Male & 62 & $24.2 \pm 0.77$ & 54 & $39.2 \pm 0.68$ & 52 & $48.6 \pm 0.89$ & 62 & $5.3 \pm 0.12$ & 54 & $6.4 \pm 0.10$ & 52 & $7.0 \pm 0.10$ \\
\hline
\end{tabular}

NS: Non significant $(\mathrm{P}>0.05)$, *: $\mathrm{P}<0.05, * *: \mathrm{P}<0.01, * * *: \mathrm{P}<0.001$

a, b, c, d: Means within the same column with different superscript differ significantly $(\mathrm{P}<0.05)$.

\section{DISCUSSION}

In this study withers height (also known as cidago height) at birth, weaning and on the 150th day was determined as 29.2, 43.3 and $54.1 \mathrm{~cm}$, respectively. Because there is limited study outcome in the same period for pure and crossbred hair goat, the morphological results of this research on the 150th day were discussed with different age finding. The value of withers height found at the weaning time was lower than from Simsek \& Bayraktar (2006)'s Saanen x Hair Goat F1 crossbred (SHF1) and HG and also from Tozlu (2006)'s SHF1 crossbred and HG. However, it was similar to Y1lmaz et al.'s SHF1 crossbred and HG. In addition to that the value of withers height found at the 180th day was also lower than Simsek \& Bayraktar's SHF1 and HG. However, it was also similar to Y1lmaz et al.'s SHF1 crossbred and HG. Surprisingly it was much lower in value in comparison to Khan et al. (2006)'s 04-12 month Beetal goat kids and Hirakawa et al. (2007)'s over 12 months Boer goat.
In search of the main affects that weaning had on the withers height, few parameters such as the age of the mother, sex, birth type, genotype and weight of the animal were all investigated. First of all, the age of the mother was investigated. It had no significant effect on the withers height and the results were compatible with the findings of Simsek \& Bayraktar and Yilmaz et al.. Secondly the sex effect was investigated. It had significant effect on the withers height. The results were compatible with the findings of Simsek \& Bayraktar and Yilmaz et al. Thirdly the birth type was examined. It had also significant effect on the withers height. The results were compatible with the findings of Simsek \& Bayraktar but it was incompatible with the findings of Yilmaz et al. Fourthly, genotype was investigated. It had also significant effect on the withers height. The results were compatible with the findings of Tozlu and unfortunately it was incompatible with the findingsof Simsek \& Bayraktar and Yilmaz et al. 
BOLACALI, M.; ÖZTÜRK,Y.; YILMAZ, O.; KÜÇÜK, M. \& KARSLI, M. A. Investigation of some morphological traits of Boer x Hair F1 crossbred and pure hair goat kids raised in semiintensive conditions. Int. J. Morphol., 35(4):1502-1511, 2017.

Table VI. Least square means, significance and multiple comparison test results for chest width and front-rump width of goats at different periods $(\mathrm{cm})$.

\begin{tabular}{|c|c|c|c|c|c|c|c|c|c|c|c|c|}
\hline \multirow{3}{*}{ Factors } & \multicolumn{6}{|c|}{ Chest width } & \multicolumn{6}{|c|}{ Front-rump width } \\
\hline & \multirow[b]{2}{*}{$\mathrm{n}$} & \multicolumn{3}{|c|}{$\begin{array}{l}60^{\text {th }} \text { day } \\
\text { (weaning) }\end{array}$} & \multicolumn{2}{|c|}{$150 \mathrm{t}^{\mathrm{h}}$ day } & \multicolumn{2}{|r|}{ Birth } & \multicolumn{2}{|c|}{$\begin{array}{l}60 \mathrm{t}^{\mathrm{h}} \text { day } \\
\text { (weaning) }\end{array}$} & \multicolumn{2}{|c|}{$150^{\text {th }}$ day } \\
\hline & & Mean \pm SD & $\mathrm{n}$ & Mean \pm SD & $\mathrm{n}$ & Mean \pm SD & $\mathrm{n}$ & Mean \pm SD & $\mathrm{n}$ & Mean \pm SD & $\mathrm{n}$ & Mean \pm SD \\
\hline General & 125 & $5.9 \pm 0.14$ & 107 & $9.0 \pm 0.14$ & 104 & $10.4 \pm 0.14$ & 125 & $6.1 \pm 0.12$ & 107 & $9.4 \pm 0.12$ & 104 & $11.3 \pm 0.12$ \\
\hline Genotype & & $*$ & & $* *$ & & $* *$ & & NS & & NS & & NS \\
\hline $\mathrm{BH}$ & 80 & $5.9 \pm 0.21$ & 68 & $9.2 \pm 0.22$ & 66 & $10.6 \pm 0.20$ & 80 & $6.0 \pm 0.19$ & 68 & $9.3 \pm 0.14$ & 66 & $11.1 \pm 0.18$ \\
\hline HG & 45 & $5.0 \pm 0.28$ & 39 & $7.9 \pm 0.30$ & 38 & $9.5 \pm 0.27$ & 45 & $5.6 \pm 0.26$ & 39 & $9.1 \pm 0.20$ & 38 & $10.7 \pm 0.24$ \\
\hline Dame Age & & NS & & NS & & NS & & NS & & NS & & NS \\
\hline 2 & 19 & $5.1 \pm 0.31$ & 15 & $8.8 \pm 0.34$ & 15 & $10.3 \pm 0.31$ & 19 & $5.9 \pm 0.29$ & 15 & $9.3 \pm 0.23$ & 15 & $11.1 \pm 0.28$ \\
\hline 3 & 18 & $5.6 \pm 0.43$ & 13 & $8.5 \pm 0.43$ & 12 & $9.6 \pm 0.40$ & 18 & $6.3 \pm 0.39$ & 13 & $9.4 \pm 0.29$ & 12 & $11.0 \pm 0.35$ \\
\hline 4 & 22 & $5.5 \pm 0.38$ & 20 & $8.3 \pm 0.41$ & 20 & $10.2 \pm 0.38$ & 22 & $5.8 \pm 0.34$ & 20 & $9.2 \pm 0.28$ & 20 & $11.2 \pm 0.34$ \\
\hline 5 & 35 & $5.4 \pm 0.26$ & 31 & $8.4 \pm 0.28$ & 30 & $9.7 \pm 0.26$ & 35 & $5.6 \pm 0.24$ & 31 & $8.7 \pm 0.19$ & 30 & $10.7 \pm 0.22$ \\
\hline$\geq 6$ & 31 & $5.6 \pm 0.35$ & 28 & $8.7 \pm 0.38$ & 27 & $10.6 \pm 0.35$ & 31 & $5.4 \pm 0.32$ & 28 & $9.0 \pm 0.26$ & 27 & $10.8 \pm 0.31$ \\
\hline $\begin{array}{l}\text { Dam's live } \\
\text { weight, } \mathrm{kg}\end{array}$ & & NS & & NS & & NS & & NS & & $* *$ & & NS \\
\hline $30.01-35.00$ & 24 & $5.4 \pm 0.33$ & 19 & $7.8 \pm 0.37$ & 18 & $9.7 \pm 0.34$ & 24 & $5.6 \pm 0.30$ & 19 & $8.5 \pm 0.25 \mathrm{c}$ & 18 & $10.6 \pm 0.30$ \\
\hline $35.01-40.00$ & 10 & $5.3 \pm 0.37$ & 9 & $8.7 \pm 0.40$ & 9 & $10.1 \pm 0.37$ & 10 & $5.1 \pm 0.33$ & 9 & $8.4 \pm 0.27^{\mathrm{bc}}$ & 9 & $10.6 \pm 0.33$ \\
\hline $40.01-45.00$ & 31 & $5.6 \pm 0.31$ & 27 & $8.5 \pm 0.33$ & 26 & $10.3 \pm 0.31$ & 31 & $6.0 \pm 0.28$ & 27 & $9.2 \pm 0.23 \mathrm{a}^{\mathrm{bc}}$ & 26 & $10.8 \pm 0.27$ \\
\hline $45.01-50.00$ & 39 & $5.5 \pm 0.24$ & 33 & $8.8 \pm 0.27$ & 32 & $10.3 \pm 0.24$ & 39 & $6.2 \pm 0.22$ & 33 & $9.7 \pm 0.18^{\mathrm{ab}}$ & 32 & $11.2 \pm 0.22$ \\
\hline$\geq 50.01$ & 21 & $5.5 \pm 0.34$ & 19 & $8.8 \pm 0.38$ & 19 & $10.1 \pm 0.35$ & 21 & $6.1 \pm 0.32$ & 19 & $10.0 \pm 0.26 \mathrm{a}$ & 19 & $11.6 \pm 0.31$ \\
\hline Birth Type & & $* * *$ & & NS & & $* *$ & & $* * *$ & & $* * *$ & & $* * *$ \\
\hline Single & 73 & $6.2 \pm 0.17^{\mathrm{a}}$ & 67 & $9.1 \pm 0.19$ & 66 & $10.7 \pm 0.17^{\mathrm{a}}$ & 73 & $6.5 \pm 0.16^{\mathrm{a}}$ & 67 & $10.0 \pm 0.13 \mathrm{a}$ & 66 & $11.7 \pm 0.15^{\mathrm{a}}$ \\
\hline Twin & 42 & $5.7 \pm 0.22^{\mathrm{a}}$ & 32 & $8.5 \pm 0.24$ & 30 & $10.0 \pm 0.23^{\mathrm{b}}$ & 42 & $6.0 \pm 0.20^{\mathrm{a}}$ & 32 & $9.1 \pm 0.17 \mathrm{~b}$ & 30 & $10.9 \pm 0.20 \mathrm{~b}$ \\
\hline$\geq$ Triplets & 10 & $4.4 \pm 0.37^{\mathrm{b}}$ & 8 & $8.0 \pm 0.42$ & 8 & $9.6 \pm 0.38 \mathrm{~b}$ & 10 & $4.9 \pm 0.34 \mathrm{~b}$ & 8 & $8.4 \pm 0.28 b$ & 8 & $10.2 \pm 0.34 \mathrm{~b}$ \\
\hline $\operatorname{Sex}$ & & $*$ & & NS & & NS & & $*$ & & $*$ & & NS \\
\hline Female & 63 & $5.2 \pm 0.20$ & 53 & $8.4 \pm 0.22$ & 52 & $10.1 \pm 0.20$ & 63 & $5.5 \pm 0.18$ & 53 & $9.0 \pm 0.14$ & 52 & $10.8 \pm 0.18$ \\
\hline Male & 62 & $5.7 \pm 0.21$ & 54 & $8.6 \pm 0.23$ & 52 & $10.0 \pm 0.21$ & 62 & $6.1 \pm 0.19$ & 54 & $9.4 \pm 0.16$ & 52 & $11.0 \pm 0.19$ \\
\hline
\end{tabular}

NS: Non significant $(\mathrm{P}>0.05), *: \mathrm{P}<0.05, * *: \mathrm{P}<0.01, * * *: \mathrm{P}<0.001$.

$\mathrm{a}, \mathrm{b}, \mathrm{c}$ : Means within the same column with different superscript differ significantly $(\mathrm{P}<0.05)$.

Finally weight of the animal was investigated. The results were insignificant and it was compatible with the findings of Yilmaz et al.

In light of this study, the general body length at birth, weaning and the 150th day was $29.0,44.3$ and $53.8 \mathrm{~cm}$, respectively. At weaning, the general body length value found was lower than those of values reported by Yilmaz et al. for SHF1 crossbred and HG. However, it was similar to the values reported by Yilmaz et al. and Tozlu for SHF1 crossbred and $\mathrm{HG}$ values. At the 150th day, the general body length value found was similar to those of values reported by Yilmaz et al. for SHF1 crossbred and HG. However, it was higher than those values reported by Simsek \& Bayraktar for SHF1 crossbred and HG. However, it was much lower in value in comparison to those values reported by Khan et al. for 04-12 month Beetal goat kids and Hirakawa et al. for over 12 months Boer goat.

First of all, our results indicated the significance of the genotype effect on the body length. This finding was incompatible with the finding of Simsek \& Bayraktar and 
Table VII. Least square means, significance and multiple comparison test results for midrump width of goats at different periods $(\mathrm{cm})$.

\begin{tabular}{|c|c|c|c|c|c|c|}
\hline \multirow[t]{2}{*}{ Factors } & \multicolumn{2}{|c|}{ Birth } & \multicolumn{2}{|c|}{$\begin{array}{c}60 \mathrm{t}^{\mathrm{h}} \text { day } \\
\text { (weaning) }\end{array}$} & \multicolumn{2}{|c|}{$150^{\text {th }}$ day } \\
\hline & $\mathrm{n}$ & Mean \pm SD & $\mathrm{n}$ & Mean \pm SD & $\mathrm{n}$ & Mean \pm SD \\
\hline General & 125 & $8.3 \pm 0.13$ & 107 & $11.6 \pm 0.13$ & 104 & $13.4 \pm 0.13$ \\
\hline Genotype & & $* * *$ & & NS & & $* *$ \\
\hline $\mathrm{BH}$ & 80 & $8.7 \pm 0.19$ & 68 & $11.3 \pm 0.18$ & 66 & $13.2 \pm 0.17$ \\
\hline HG & 45 & $7.4 \pm 0.26$ & 39 & $10.8 \pm 0.24$ & 38 & $11.9 \pm 0.23$ \\
\hline Dame Age & & NS & & NS & & NS \\
\hline 2 & 19 & $8.0 \pm 0.29$ & 15 & $11.3 \pm 0.28$ & 15 & $13.3 \pm 0.26$ \\
\hline 3 & 18 & $8.4 \pm 0.40$ & 13 & $11.1 \pm 0.34$ & 12 & $13.0 \pm 0.33$ \\
\hline 4 & 22 & $8.4 \pm 0.34$ & 20 & $11.3 \pm 0.33$ & 20 & $13.5 \pm 0.31$ \\
\hline 5 & 35 & $7.8 \pm 0.24$ & 31 & $10.9 \pm 0.23$ & 30 & $12.8 \pm 0.21$ \\
\hline$\geq 6$ & 31 & $7.6 \pm 0.33$ & 28 & $10.8 \pm 0.31$ & 27 & $12.6 \pm 0.30$ \\
\hline Dam's live weight, $\mathrm{kg}$ & & NS & & $*$ & & $* *$ \\
\hline $30.01-35.00$ & 24 & $7.9 \pm 0.31$ & 19 & $10.4 \pm 0.30^{\mathrm{b}}$ & 18 & $12.4 \pm 0.29^{\mathrm{b}}$ \\
\hline $35.01-40.00$ & 10 & $7.9 \pm 0.34$ & 9 & $10.5 \pm 0.32 \mathrm{a}^{\mathrm{b}}$ & 9 & $12.4 \pm 0.31^{\mathrm{a}}$ \\
\hline $40.01-45.00$ & 31 & $8.1 \pm 0.29$ & 27 & $11.1 \pm 0.27^{\mathrm{a}}$ & 26 & $12.9 \pm 0.26^{\mathrm{a}}$ \\
\hline $45.01-50.00$ & 39 & $8.2 \pm 0.23$ & 33 & $11.6 \pm 0.22^{\mathrm{a}}$ & 32 & $13.7 \pm 0.21 \mathrm{a}$ \\
\hline$\geq 50.01$ & 21 & $8.1 \pm 0.33$ & 19 & $11.7 \pm 0.31^{\mathrm{a}}$ & 19 & $13.9 \pm 0.30 \mathrm{a}$ \\
\hline Birth Type & & $*$ & & $* * *$ & & $* * *$ \\
\hline Single & 73 & $8.5 \pm 0.16^{\mathrm{a}}$ & 67 & $12.0 \pm 0.15^{\mathrm{a}}$ & 66 & $14.0 \pm 0.14 \mathrm{a}$ \\
\hline Twin & 42 & $8.1 \pm 0.20 \mathrm{~b}$ & 32 & $11.2 \pm 0.20^{\mathrm{b}}$ & 30 & $13.1 \pm 0.19^{\mathrm{b}}$ \\
\hline$\geq$ Triplets & 10 & $7.5 \pm 0.34 \mathrm{~b}$ & 8 & $9.9 \pm 0.34^{\mathrm{c}}$ & 8 & $12.1 \pm 0.32^{\mathrm{b}}$ \\
\hline Sex & & NS & & $*$ & & * \\
\hline Female & 63 & $7.9 \pm 0.19$ & 53 & $10.9 \pm 0.18$ & 52 & $12.9 \pm 0.17$ \\
\hline Male & 62 & $8.1 \pm 0.20$ & 54 & $11.3 \pm 0.19$ & 52 & $13.3 \pm 0.18$ \\
\hline
\end{tabular}

NS: Non significant $(\mathrm{P}>0.05), *: \mathrm{P}<0.05, * *: \mathrm{P}<0.01, * * *: \mathrm{P}<0.001$

$\mathrm{a}, \mathrm{b}, \mathrm{c}$ : Means within the same column with different superscript differ significantly $(\mathrm{P}<0.05)$.

for SHF1 crossbred and HG and it was much lower than the values found by Yilmaz et al. for SHF1 crossbred and HG.

First of all, our results indicated the significance of the genotype effect on the heart girth. This finding was compatible with Tozlu's findings. However, it was incompatible with reported by Yilmaz et al. Secondly, the age of the mother was found to be ineffective on the heart girth. This finding was compatible with values reported by Simsek \& Bayraktar, but was incompatible with Yllmaz et al. findings. Thirdly, our results depicted the significance of the animals' weight. This was also supported by Yllmaz et al. findings. Finally, our results indicated that both the effect of birth type and sex was compatible with values reported by Simsek \& Bayraktar. Whereas it was incompatible with results reported by Yilmaz et al.

\section{CONCLUSION}

Yilmaz et al. Secondly, our results showed the ineffectiveness of the age of the mother. This finding was compatible with the finding of Simsek \& Bayraktar and Yilmaz et al. Thirdly, our results depicted the insignificance of the mother's weight. This finding was compatible with the finding of Y1lmaz et al. Fourthly, our results indicated the importance of the birth type effect. This finding was compatible with the results reported by Simsek \& Bayraktar. However, it was incompatible with the findings of Yilmaz et al. Finally, our results showed the importance of sex effect. This finding was compatible with the results reported by Tozlu, but it was incompatible with the findings of Yilmaz et al.

In this research, the heart girth at birth, weaning and the 150th day was $31.1,52.3$ and $61.3 \mathrm{~cm}$, respectively. At weaning, the heart girth value found was similar to those of the values reported by Yilmaz et al. and Simsek \& Bayraktar for SHF1 crossbred and HG. However, the value was lower than those of the values reported by Tozlu for SHF1 crossbred and HG. At the 150th day, the heart girth was higher than the values found by Khan et al. for 04-12 month Beetal breed. This value was similar to the values of Simsek \& Bayraktar
To conclude, although there is not much information on morphological parameters literature in Boer and Hair goat, in this study morphological parameters of the Boer x Hair Goat F1 crossbred and pure Hair Goat kids were compared. It was found that the Boer x Hair Goat F1 crossbred are much better than the Hair Goats kids for both morphological and zoometric values. Hence, the widespread crossbreeding of the Boer goat would result in an increase of profit in goat production and would greatly contribute to the countries' economic growth.

BOLACALI, M.; ÖZTÜRK,Y.; YILMAZ, O.; KÜÇÜK, M. \& KARSLI, M. A. Investigación de algunos rasgos morfológicos en caprinos de pelaje natural raza boer x cruzados y criados en condiciones semi-intensivas. Int. J. Morphol., 35(4):1502-1511, 2017.

RESUMEN: El objetivo del estudio fue determinar varias características morfológicas desde el nacimiento hasta la edad de 150 días en caprinos Boer x Hair goat F1 crossbred (BH) y Cabra pura (HG) criados en condiciones semi-intensivas y revelar factores tales como los efectos del genotipo, la edad, el peso vivo de la 
el tipo de nacimiento y el sexo entre otros. Este estudio fue realizado entre los años 2011-2012 en Çatak, región de Van y entre los años 2013-2014 en la Granja de Investigación y Práctica de la Universidad Yuzuncu Yil. Se estudiaron diversas medidas corporales: Altura del talón, altura de la espalda, altura de la grupa, altura del sacro, longitud del cuerpo, longitud del pecho, profundidad del tórax, circunferencia del pecho, circunferencia de la pierna, circunferencia del hueso del cañón, ancho del pecho, ancho de la grupa delantera y anchura media de la grupa, así se determinaron $29.8,28.4,28.7,26.2,28.7,17.0,13.3,30.4,26.9,5.2,5.9,6.0$ y $8.7 \mathrm{~cm}$ al nacer, respectivamente; $43.8,43.8,44.6,40.6,43.6,22.2$, $19.3,51.7,41.4,6.6,9.2,9.3$ y $11.3 \mathrm{~cm}$ en el $60^{\circ}$ día, respectivamente; 56.1, 53.4, 54.4, 47.5, 53.3, 27.3, 24.1, 61.4, 49.6, 7.3, 10.6, 11.1 y $13.2 \mathrm{~cm}$ en 150 días, respectivamente para niños $\mathrm{BH} ; 27.3$, $25.9,29.3,25.3,27.1,15.9,12.3,29.0,21.3,5.1,5.0,5.6$ y $7.4 \mathrm{~cm}$ al nacimiento, respectivamente; 40,4, 40,1, 42,9, 37,6, 40,5, 22,3, $18,4,48,1,36,4,6,0,7,9,9,1$ y $10,8 \mathrm{~cm}$ en el $60^{\circ}$ día, respectivamente; 50.3, 49.2, 51.0, 45.7, 50.4, 27.5, 22.9, 57.3, 43.4, 6.5, 9.5, 10.7 y $11.9 \mathrm{~cm}$ a los 150 días, respectivamente, para cabritos HG. Cuando se consideraron todos los datos, se concluyó que los cabritos $\mathrm{BH}$ son mucho mejores que los cabritos HG para los valores morfológicos y zoométricos.

PALABRAS CLAVE: Boer x Hair goat F1 crossbred; Cabra de pelo; Niños; Rasgos morfológicos.

\section{REFERENCES}

Akçapınar, H. \& Özbeyaz, C. Basic Information of Animal Breeding. Ankara, 1999.

Daskiran, I.; Bingol, M.; Karaca, S.; Yilmaz, A.; Cetin, A. O. \& Kor, A. The effect of feeding system on fattening performance, slaughter, and carcass characteristics of Norduz male kids. Trop. Anim. Health Prod., 42(7): 1459-63, 2010.

Devendra, C. \& Burns, M. Goat Production in The Tropics. $2^{\text {nd }}$ ed. Farnham Royal, Commonwealth Agricultural Bureaux, 1984.

Epstein, H. The Origin of the Domestic Animal in Africa. New York, Africana Publishing Corporation, 1953.

Food and Agriculture Organization of the United Nations (FAO). Live Animals. Rome, Food and Agriculture Organization of the United Nations, 2016. Available from: http://faostat.fao.org/site/573/ default.aspx\#ancor

Hirakawa, M.; Arasaki, Y.; Sunagawa, K. \& Shinjo, A. The season of delivery, litter size and body measurement in Boer goats. Nihon Chikusan Gakkaiho, 78(1):15-20, 2007.

Khan, H.; Muhammad, F.; Ahmad, R.; Nawaz, G.; Rahimullah \& Zubair, M. Relationship of body weight with linear body measurements in goats. J. Agric. Biol. Sci., 1(3):51-4, 2006.

Malan, S. W. The improved Boer goat. Small Rum. Res., 36(2):165-70, 2000

Mason, I. L. A World Dictionary of Livestock Breeds, Types and Varietes. Wallingford, CABI, 1988.

Mohammed, I. D. \& Amin, J. D. Estimating body weight from morphometric measurements of Sahel (Borno White) goats. Small Rum. Res., 24(1):1$5,1997$.

Olatunji-Akioye, A. O. \& Adeyemo, O. K. Liveweight and chest girth correlation in commercial sheep and goat herds in Southwestern Nigeria. Int. J. Morphol., 27(1):49-52, 2009.
Özcan, L. The Possibilities of Using Saanen and G1 Genotypes in Breeding Kilis and Hair Goats Were Studies on The Material Grown at The University of Çukurova Faculty of Agriculture. Adana, Kemal Press, 1977.

Riva, J.; Rizzi, J.; Marelli, S. \& Cavalchini, L. G. Body measurements in Bergamasca sheep. Small Rum. Res., 55(1-3):221-7, 2004.

SAS. Institute Inc. SAS User's Guide: Statistics. Version 9.1. Cary, SAS Institute, 2002.

Simsek, U. G. \& Bayraktar, M. Investigation of growth rate and survivability characteristics of pure Hair goats andSaanen x pure Hair goats Crossbreeds (F1). Firat Univ. Vet. J. Health Sci., 20(3):229-38, 2006.

Tozlu, H. Comparison of Saanen X Hair (F1) Crossbred Goats with Pure Hair Goats Raised in Amasya Province Pure Hair Goat Improvement Project in Terms of Growth and Other Raising Traits. Master's Thesis. Samsun, University of Ondokuz Mayıs, Institute of Science, 2006.

TUIK. Turkish Statistical Institute, Livestock Statistics. 2016. Available from: https://biruni.tuik.gov.tr/hayvancilikapp/hayvancilik.zul

Ugur, F.; Savas, T.; Dosay, M.; Karabayır, A. \& Atasoglu, C. Growth and behavioral traits of Turkish Saanen kids weaned at 45 and 60 days. Small Rum. Res., 52(1-2):179-84, 2004.

Urge, M.; Merkel, R. C.; Sahlu, T.; Animut, G. \& Goetsch, A. L. Growth performance by Alpine, Angora, Boer and Spanish wether goats consuming 50 or $75 \%$ concentrate diets. Small Rum. Res., 55(1-3):14958, 2004.

Yılmaz, O., Kucuk, M.; Bolacalı, M. \& Cak, B. Investigation of survival rate, growth performance and some body measurements of Saanen $\mathrm{x}$ Hair Goat F1 crossbred and pure hair goat kids raised in semi-intensive conditions. Bulg. J. Agric. Sci., 19(4):835-40, 2013.

\section{Corresponding author:}

Memis Bolacali

Assistant Professor of Animal Breeding and Husbandry

Department of Animal Breeding and Husbandry

Faculty of Veterinary Medicine

University of Siirt

Siirt

TURKEY

\section{Email: bolacali@gmail.com bolacali@siirt.edu.tr}

Recibido: 18-11-2016

Aceptado:27-07-2017 